\title{
Perancangan Komunikasi Visual Nopia sebagai Kuliner Khas Kabupaten Banyumas
}

\author{
Elfa Swaratama \\ Mahasiswa Penciptaan Desain Komunikasi Visual \\ Program Pascasarjana Institut Seni Indonesia Yogyakarta \\ elfaswaratama@gmail.com
}

\begin{abstract}
Nopia is a cake from Banyumas that is round with smooth texture, crisp outside, but soft in the middle section. Based on a survey, 54\% doesn't respondents don't know it's name, 45\% doesn't know it's origin, and 86\% doesn't know that this cake is cooked with barrel. This design will make a visual communication that will broaden the target audience about nopia.

Data collection methods used in this design are participatory observation, interviews, documentation, and library, as well as this design through the four stages, namely the manufacture of the design concept, creative concept, the concept of media, and visualization.

Based on data collected, be concluded that the target audience has a solid rushing. They spent more time in digital media which a lot of communications made through applications on their smartphone and did not like being outside the home with a long period of time. They just travel outside if they want to buy daily necessities only and often shopping in modern supermarkets. Therefore, the design will use 3 medias which are packaging, floor display, and social media accounts such as Facebook and Instagram.
\end{abstract}

Keywords: cake, digital, nopia, packaging, visual communication design

Relevance to Visual Communication Design Practice: This design uses visual communication approach as a way to introduce insights about the Nopia.

\section{PENDAHULUAN}

Kuliner merupakan kata serapan dari culinary, yaitu hal-hal yang berkaitan dengan kegiatan konsumsi dan memasak. Dalam perkembangannya, penggunaan istilah kuliner digunakan untuk berbagai macam kegiatan, seperti Seni kuliner yaitu seni persiapan, memasak dan penyajian makanan, biasanya dalam bentuk makanan. Ada juga wisata kuliner yaitu wisata yang bertujuan untuk mencoba menikmati hasil masakan di tempat wisata tersebut.

Nopia adalah kue khas kabupaten Banyumas berbentuk bulat dengan tekstur yang halus, renyah diluar, tapi lembut dibagian tengahnya. Saat ini Nopia dan Mino tidak hanya tersedia di wilayah Banyumas, namun dapat ditemui di berbagai toko oleholeh di beberapa kota seperti Wonosobo, Gombong, Cilacap, Yogyakarta, hingga Surabaya, namun pusat produksinya tersedia di wilayah kabupaten Banyumas. Kue nopia merupakan kuliner yang menarik, karena merupakan akulturasi budaya Tionghoa dengan Jawa. Proses pembuatannya pun menarik, karena menggunakan gentong sebagai pemanas sederhana.

Namun, Nopia sebagai kuliner khas Banyumas ternyata tidak banyak orang yang tahu. Berdasarkan data survey yang diambil dari tanggal 1-7 Maret 2016 kepada 37 orang 
responden, kurang dari setengah responden mengetahui bahwa kuliner yang dimaksud adalah Nopia. Bahkan, sebagian responden mengira bahwa makanan yang dimaksud adalah Bakpia.

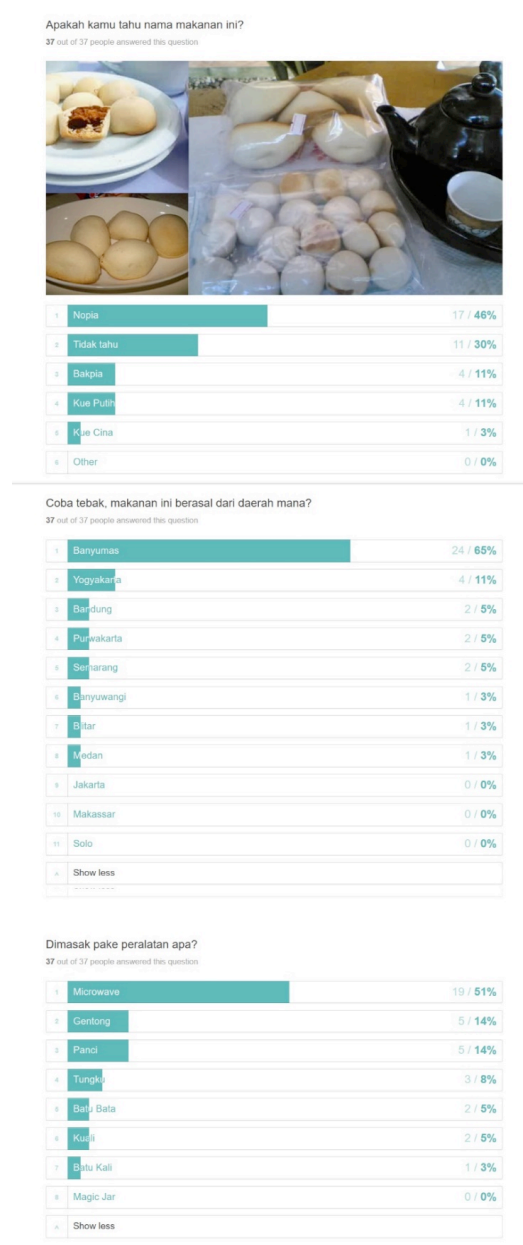

Gambar 1 Kesimpulan data kuisioner Sumber: Elfa Swaratama

$51 \%$ responden masih belum tahu bahwa kue Nopia dibuat dengan cara yang tradisional, mereka masih menganggap bahwa Nopia dibuat menggunakan cara yang modern, yaitu microwave. Hal tersebut sangat disayangkan, karena salah satu faktor yang membentuk sebuah kategori kuliner adalah faktor tradisi. Sebagai salah satu kue pia khas
Indonesia, proses pembuatan nopia yang sangat tradisional merupakan hal yang menjadikan ciri khas kue pia ini dibandingkan dengan kue pia khas Indonesia yang lain.

Teori-teori yang akan digunakan dalam perancangan ini akan meliputi teori yang membahas akulturasi budaya tionghoa dengan Banyumas yang melahirkan kuliner Nopia. Akulturasi dapat dipahami sebagai meliputi fenomen yang timbul jika kelompokelompok manusia yang mempunyai kebudayaan yang berbeda bertemu dan mengadakan kontak secara langsung dan terus -menerus yang mengakibatkan perubahan dalam pola kebudayaan dari salah satu atau kedua belah pihak yang terlibat dalam proses tersebut. (Kusumohamidjojo, 2009: 190)

Perlu dirancang suatu komunikasi visual yang tepat sehingga dapat menggantikan penjelasan yang kompleks menjadi suatu komunikasi visual yang sederhana dan "berbicara". Desain yang dibuat haruslah mengubah paradigma target audiens yang menyangka bahwa kue nopia dibuat dengan peralatan modern. Perancangan ini akan menggunakan media utama yang didasarkan dari consumer journey dan media-media pendukung berupa brand activation.

\section{METODE PERANCANGAN}

Perancangan ini secara garis besar dirancang dengan melalui tiga tahap yakni:

\section{Konsep Desain}

Demi keefektifan dalam penyampaian pesan maka secara visual akan diarahkan sesuai dengan komposisi yang sudah ditentukan. 
Pengarahan visual akan dibagi kedalam 4 elemen desain, yaitu layout, ilustrasi, warna, dan tipografi.

\section{Konsep Pesan Verbal dan Visual}

Tahapan ini menentukan hal-hal yang akan dilakukan demi mencapai tujuan dari perancanga. Konsep Pesan Verbal dan Visual dibagi menjadi 3, yaitu konsep kreatif, tujuan kreatif, dan strategi kreatif.

\section{Konsep Media}

Konsep ini berhubungan dengan mediamedia terpilih yang akan digunakan dalam perancangan ini. Konsep media memegang peran penting karena berkaitan dengan pemilihan media-media yang efektif dan komunikatif dalam rangka keberhasilan perancangan komunikasi visual.

\section{Visualisasi}

Tahapan terakhir ini akan mengeksekusi visual berdasarkan dari konsep desain, konsep pesan verbal dan visual, serta konsep media yang telah dibuat.

Metode Pengumpulan Data yang digunakan dalam perancangan ini menggunakan informasi yang didapatkan dari beberapa metode, yaitu:

1. Observasi Partisipatoris, yaitu berpartisipasi langsung dalam proses pembuatan kue nopia

2. Wawancara, yaitu dilakukan untuk mendapatkan data secara langsung dari narasumber dalam bentuk lisan. Narasumber yang dipilih dalam penelitian ini berdasarkan lingkup objek yang dipilih yaitu produsen kue Nopia.
Mencari sumber-sumber literatur yang berasal dari buku dan internet

3. Dokumentasi, yaitu berupa foto dan video yang berkaitan proses pembuatan kue nopia.

4. Pustaka, yaitu mengumpulkan informasi yang bersifat teoritis dan tertulis dari hasil berbagai penelitian sebelumnya.

Metode yang digunakan dalam proses analisis data menggunakan analisis $5 \mathrm{~W}+1 \mathrm{H}$ (What, Who, Why, Where, When, dan How). Data yang dikumpulkan dapat diambil sebagai bahan untuk dillakukan analisis. Hasil analisis ini mengetahui berbagai macam kelemahan dan kelebihan. Berikut analisis secara detailnya:

\section{What}

Perancangan ini dibuat dalam bentuk karya desain yang informatif dan komunikatif, dimana akan menjelaskan tentang proses pembuatan kue nopia dan mino. Dalam karya desain tersebut akan terkandung nilai kearifan lokal yaitu unsur tradisi penggunaan gentong sebagai alat pembuat kue nopia dan mino.

\section{Who}

Perancangan ini merujuk pada target audiens anak muda usia antara 20-30 tahun yang memiliki tempat tinggal di kota-kota yang berada di wilayah distribusi nopia, yaitu Banyumas,Wonosobo, Gombong, Cilacap, Yogyakarta, dan Surabaya. 
3. Why

Perancangan dibuat karena kurangnya pemahaman tentang kue nopia sebagai kuliner khas Banyumas

\section{Where}

Karena jangkauannya yang luas, maka akan melakukan perancangan kemasan nopia edisi khusus dan media-media berupa brand activation.

\section{When}

Perancangan ini akan diluncurkan bertepatan pada hari jadi kabupaten Banyumas, yaitu pada tanggal 22 Februari 2017.

\section{How}

Untuk menjalankan perancangan ini diperlukan suatu perancangan komunikasi visual untuk menginformasikan pesan dan memberikan pengaruh pada target audiens untuk lebih mengerti tentang nilai kearifan lokal kue nopia sebagai makanan khas Banyumas.

\section{NOPIA SEBAGAI KULINER KHAS BANYUMAS}

Nopia merupakan kue kering yang terbuat dari adonan tepung terigu dan diisi dengan gula merah serta dipanggang dengan tungku khusus yang terbuat dari tanah liat dan menggunakan kayu bakar dari pelepah pohon kelapa. Kue kering yang mirip dengan bakpia ini memiliki tekstur kulit mirip dengan cangkang telur yang renyah pada bagian luarnya dan berisi adonan gula merah dengan rasa bawang merah goreng. Seiring perkembangannya, nopia memiliki berbagai varian rasa yaitu coklat, durian, nangka, pandan, bawang merah goreng, serta rasa khas gula jawa (gula kelapa).

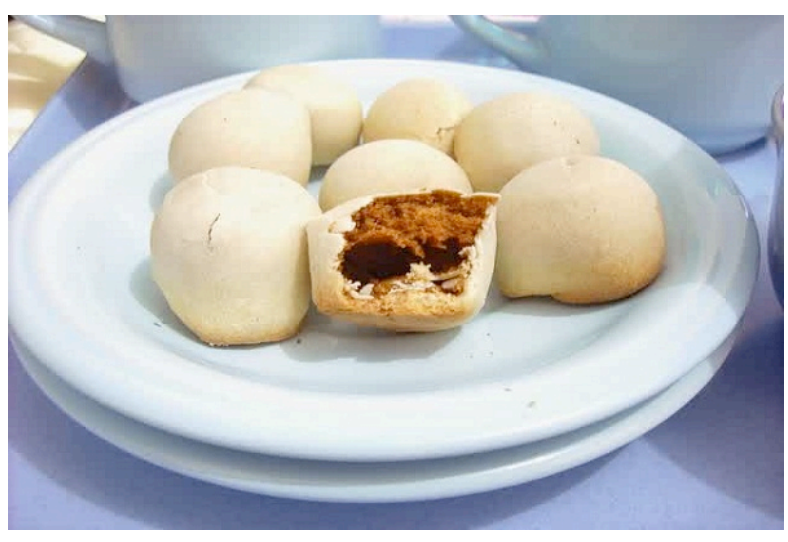

Gambar 2 Kue Nopia Sumber:

http://www.masakandapurku.com/2015/09/resepmembuat-kue-mino-nopia-khas.html)

Tekstur kulit nopia yang mirip dengan cangkang telur menjadikan kue ini memiliki banyak nama sebutan dari para penikmatnya. Ndog Gludhug dalam bahasa Banyumasan yang memiliki arti telur halilintar sudah melekat sebagai nama populer dari nopia. Sementara nopia yang dibuat dengan ukuran yang lebih besar biasa disebut sebagai telur gajah. Selain sebutan telur halilintar dan telur gajah, ada nama lain yang juga populer untuk menyebut nopia, yakni mino. Mino adalah kependekan kata dari Mini Nopia, alasannya mino dibuat dengan ukuran yang lebih kecil dari ukuran nopia pada biasanya. Penyebutan nopia kecil dengan nama mino sering membuat orang dari luar daerah Banyumas beranggapan bahwa nopia dan mino adalah berbeda, padahal sebetulnya sama hanya mino dibuat dengan ukuran yang lebih kecil.

Saat ini Nopia dan Mino tidak hanya tersedia di wilayah Banyumas, namun dapat ditemui di berbagai toko oleh-oleh di kotakota besar di pulau Jawa, Sumatra, dan Kalimantan. Namun pusat produksinya 
tersedia di wilayah Banyumas. Nopia mulai diproduksi pada tahun 1880 oleh Ting Sing Piang, yaitu seorang etnis Tionghoa yang tinggal di Banyumas (Dharmawan, 2010) Kue kering ini kemudian dikenalkan pada masyarakat lokal Banyumas tanpa mengenal etnik dan latar belakangnya, hingga bisa diterima oleh masyarakat pada saat itu. Industri kecil pembuatan nopia kemudian berkembang di beberapa desa di kawasan Kota Lama Banyumas. Nopia merupakan kuliner akulturasi budaya yang hingga saat ini masih dilestarikan oleh masyarakat Banyumas.

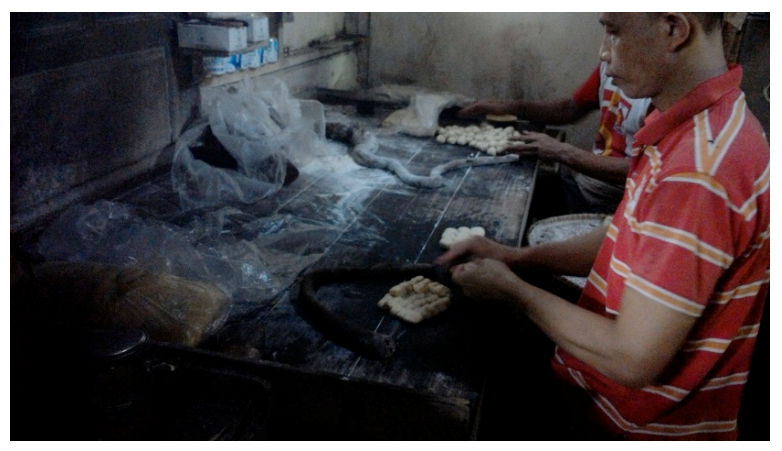

Gambar 3 Proses pembuatan kue Nopia Sumber: Elfa Swaratama

Nopia terdiri dari kulit dan isian. Kulit nopia dibuat dengan cara mencampurkan tepung terigu protein rendah, gula, vanili, dengan air lalu diaduk-aduk sampai menjadi adonan. Adonan itu dijadikan bulatan kecilkecil sebesar ibu jari tangan. Bulatan dipipihkan dengan tangan, di tengahnya diisi oleh isian yang sudah dihancurkan, lalu dibulatkan lagi. Isian dibuat dari campuran tepung terigu protein sedang, gula jawa, susu kental manis, gula pasir, minyak goreng, dan air.

Bulatan-bulatan tersebut kemudian dipanggang menggunakan gentong yang bentuknya menyerupai mangkuk. Gentong tersebut dibalik lalu dilapisi oleh susunan bata dan semen. Setelah itu susunan bata dan semen tersebut dilapisi lagi dengan anyaman bambu. Hal tersebut dilakukan untuk menjaga suhu dalam gentong tetap panas dikala sisi luar tidak terlalu panas. Karena pada proses pemanggangan nopia direkatkan ke dinding gentong dengan tangan dan tanpa alat lain. Gentong dan anyaman bambu khusus untuk membuat nopia dapat dibeli dari pengrajin yang berada di pasar Banyumas. Menurut penuturan seorang pembuat Nopia dan Mino, satu gentong dapat memasak 800 buah mino secara bersamaan dan dalam satu hari dapat memproduksi hingga $50 \mathrm{~kg}$ Nopia dan Mino.

Proses pemanggangannya tergolong unik, karena sebelum digunakan, kayu bakar atau arang dibakar didalam gentong tersebut hingga apinya mati dan bersuhu sekitar 45 - 50 derajat celcius. Setelah itu, kayu bakar atau arang dikeluarkan lalu gentong tersebut dipercikkan air dan didiamkan selama 15 menit untuk mendapatkan suhu yang sesuai. Setelah suhu dalam gentong sudah diarasa cukup, sisa kayu bakar yang panas dimasukkan dalam gentong kembali dan Nopia mentah ditempelkan ke dinding bagian dalam gentong tersebut. Kue ini pun akan dikerok dari dinding setelah menggelembung sekitar setengah jam didiamkan. Jika Nopia didiamkan terlalu lama dalam tungku, maka akan meletus. Meski tanpa bahan pengawet, kue Nopia dan Mino dapat bertahan sampai 3 bulan dari waktu produksinya. 


\section{ANALISA KHALAYAK SASARAN}

1. Segmentasi Khalayak Sasaran

Khalayak sasaran dalam perancangan ini, dapat dijabarkan sebagai berikut:

\section{a. Demografis}

Segmentasi demografis pada perancangan ini adalah anak muda, dengan rentang umur 20 hingga 30 tahun, memiliki tingkat ekonomi menengah ke atas dan telah menyelesaikan pendidikan strata 1 .

\section{b. Geografis}

Khalayak sasaran memiliki tempat tinggal di kota-kota yang berada di wilayah distribusi nopia, yaituseluruh pulau jawa, sumatera, hingga kalimantan.

\section{c. Psikografis}

Psikografis sasaran dalam perancangan ini ialah mereka senang untuk melakukan eksplorasi kuliner.

\section{d.Perilaku}

Perilaku sasaran yang dipilih adalah mereka yang aktif menggunakan media sosial

\section{Consumer Journey}

Consumer journey adalah jadwal kegiatan sehari-hari konsumen/khalayak sasaran. Consumer Journey dipaparkan untuk melihat media-media yang bersentuhan dengan sasaran tersebut.

Nama: Rani Permatasari

Umur: 24

Jabatan: Desainer Grafis

Instansi: SF Corporation, LLC

Tempat Tinggal: Yogyakarta
Tabel 1 Consumer journey khalayak sasaran pertama

\begin{tabular}{|c|c|c|}
\hline Waktu & Aktivitas & Point of Contact \\
\hline 07:00 & $\begin{array}{l}\text { Bangun } \\
\text { Tidur }\end{array}$ & $\begin{array}{l}\text { Cek Notifikasi } \\
\text { Handphone } \\
\text { (Whatsapp, } \\
\text { Facebook) }\end{array}$ \\
\hline $\begin{array}{l}\text { 07:00- } \\
09: 00\end{array}$ & Bekerja & $\begin{array}{l}\text { Website: Trello, } \\
\text { Gmail.com, Joox } \\
\text { Handphone: } \\
\text { Facebook, Instagram, } \\
\text { Whatsapp }\end{array}$ \\
\hline $\begin{array}{l}09: 00- \\
11: 00\end{array}$ & $\begin{array}{l}\text { Memberes } \\
\text { kan rumah } \\
\text { (Mengepel, } \\
\text { mencuci } \\
\text { baju, } \\
\text { membersih } \\
\text { kan } \\
\text { kandang } \\
\text { kucing, } \\
\text { memberi } \\
\text { makan } \\
\text { kucing) }\end{array}$ & $\begin{array}{l}\text { Botol sabun pel, } \\
\text { lemari, tempat makan } \\
\text { kucing, mesin cuci }\end{array}$ \\
\hline $\begin{array}{l}11: 00- \\
11: 30\end{array}$ & Mandi & Sabun, cermin, \\
\hline $\begin{array}{l}11: 30- \\
12: 00\end{array}$ & Makan & $\begin{array}{l}\text { Handphone: } \\
\text { Facebook, Instagram }\end{array}$ \\
\hline $\begin{array}{l}12: 00- \\
18: 00\end{array}$ & Bekerja & $\begin{array}{l}\text { Website: Trello, } \\
\text { Gmail.com, Joox } \\
\text { Handphone: } \\
\text { Facebook, Instagram, } \\
\text { Whatsapp }\end{array}$ \\
\hline $\begin{array}{l}18: 00- \\
20: 00\end{array}$ & Istirahat & $\begin{array}{l}\text { Menonton } \\
\text { Dangdut Academy, } \\
\text { Sepakbola } \\
\text { Handphone: } \\
\text { Facebook, Instagram, } \\
\text { Whatsapp, Line } \\
\text { Webtoon, 9gag }\end{array}$ \\
\hline $\begin{array}{l}20: 00- \\
22: 00\end{array}$ & Bekerja & $\begin{array}{l}\text { Website: Trello, } \\
\text { Gmail.com, Joox } \\
\text { Handphone: } \\
\text { Facebook, Instagram, } \\
\text { Whatsapp }\end{array}$ \\
\hline $22: 00$ & Tidur & Bantal, kasur, guling \\
\hline
\end{tabular}

Nama: Dimas Galih Oktavian

Umur: 26

Jabatan: Penulis Lepas

Tempat Tinggal: Yogyakarta 
Tabel 2 Consumer journey khalayak sasaran kedua

\begin{tabular}{|c|c|c|}
\hline Waktu & Aktivitas & Point of Contact \\
\hline $\begin{array}{l}\text { 05:00- } \\
06: 00\end{array}$ & $\begin{array}{l}\text { Bangun } \\
\text { Tidur }\end{array}$ & $\begin{array}{l}\text { Kamar tidur: Kasur, } \\
\text { cermin } \\
\text { Smartphone: Jam, } \\
\text { Facebook, Whatsapp, } \\
\text { Line }\end{array}$ \\
\hline $\begin{array}{l}06: 00- \\
12: 00\end{array}$ & Bekerja & $\begin{array}{l}\text { Website: Blogspot.com, } \\
\text { slideshare } \\
\text { Handphone: Facebook, } \\
\text { Instagram, Whatsapp, } \\
\text { Path }\end{array}$ \\
\hline $\begin{array}{l}12: 00- \\
13: 00\end{array}$ & Makan & $\begin{array}{l}\text { Piring, sendok, garpu } \\
\text { Website: Youtube } \\
\text { Handphone: Facebook, } \\
\text { Instagram, Whatsapp, } \\
\text { Path }\end{array}$ \\
\hline $\begin{array}{c}13: 00- \\
13: 30\end{array}$ & Mandi & Sabun, cermin, handuk \\
\hline $\begin{array}{l}13: 30- \\
16: 30\end{array}$ & $\begin{array}{l}\text { Berbelanja } \\
\text { di } \\
\text { Supermarket }\end{array}$ & $\begin{array}{l}\text { Baliho, sign system, } \\
\text { banner, } \\
\text { videotron } \\
\text { Handphone: Whatsapp, } \\
\text { Facebook, Line } \\
\text { Supermarket: } \\
\text { Banner, Floor Display, } \\
\text { Shelf Talker, Desain } \\
\text { Kemasan, }\end{array}$ \\
\hline $\begin{array}{l}16: 30- \\
17: 00\end{array}$ & $\begin{array}{l}\text { Perjalanan } \\
\text { pulang }\end{array}$ & $\begin{array}{l}\text { Baliho, sign system, } \\
\text { banner, } \\
\text { videotron }\end{array}$ \\
\hline $\begin{array}{l}17: 00- \\
19: 00\end{array}$ & Bekerja & $\begin{array}{l}\text { Website: Blog, } \\
\text { Handphone: Facebook, } \\
\text { Instagram, Whatsapp }\end{array}$ \\
\hline $\begin{array}{l}\text { 19:00- } \\
21: 00\end{array}$ & Bersantai & $\begin{array}{l}\text { Website: Youtube } \\
\text { Handphone: Facebook, } \\
\text { Instagram, Whatsapp, } \\
\text { Path }\end{array}$ \\
\hline $21: 00$ & Tidur & Bantal, kasur, guling \\
\hline
\end{tabular}

\section{Consumer Insight}

Consumer insight adalah pengaruh (biasanya sudah mengendap di alam bawah sadar) yang mengarahkan tingkah laku. Ada yang menyebutnya Forgotten Truth atau Hidden Truth. Jadi, Consumer Insight merupakan sesuatu yang tak tampak, padahal ada dan sangat berpengaruh (Kasilo, 2008:23).
Berdasarkan data consumer journey tersebut, dapat ditarik kesimpulan bahwa khalayak sasaran memiliki kesibukan yang padat. Khalayak sasaran banyak menghabiskan waktunya di media digital dan komunikasi yang dilakukan banyak melalui aplikasi di telephone genggam. Khalayak sasaran tidak suka berada diluar rumah dengan jangka waktu yang lama. Target audiens hanya bepergian kerumah jika ingin membeli kebutuhan saja. Berbicara dan mengobrol dengan teman-temannya melalui media sosial.

Khalayak sasaran senang berbelanja di supermarket modern karena barang yang dibutuhkan lebih lengkap. Setelah berbelanja disupermarket, khalayak sasaran langsung kembali kerumah.

\section{Sintesis}

Berdasarkan data diatas, maka ditentukan media-media yang paling efektif untuk menjangkau target audiens adalah sebagai berikut:

\section{a. Desain Kemasan}

Karena luasnya wilayah distribusi nopia, maka Desain Kemasan menjadi pilihan yang tepat. Perancangan ini akan membuat nopia kemasan khusus yang akan dicetak terbatas.

\section{b. Floor Display}

Berdasarkan kegemaran khalayak sasaran membeli barang di supermarket, maka floor display memegang peran penting. Dalam supermarket banyak produk bersaing untuk mendapatkan perhatian 
konsumen. Floor Display merupakan media yang tepat agar khalayak sasaran tertarik untuk mendekati rak tempat nopia disajikan.

c. Akun media sosial berupa Facebook dan Instagram

Berdasarkan consumer journey tersebut, dapat disimpulkan bahwa media yang banyak bersentuhan dengan Rani Permatasari dan Dimas Galih Oktavian adalah Handphone, dengan media sosial yang sering dibuka adalah Facebook dan Instagram

\section{KONSEP DESAIN}

Demi keefektifan dalam penyampaian pesan maka secara visual akan diarahkan sesuai dengan komposisi yang sudah ditentukan. Pengarahan visual ini akan dibagi kedalam elemen-elemen desain sebagai berikut:

\section{Layout}

Layout akan menggunakan gaya yang sederhana, karena mengutamakan efektivitas pesan sehingga semaksimal mungkin menghilangkan elemen-elemen grafis yang kiranya hanya berfungsi sebagai penghias.

\section{Ilustrasi/Gaya Visual}

Gaya visual akan menggunakan desain vector dimana memiliki garis yang tegas dan jelas. Mengingat perancangan ini akan menggunakan media digital, secara umum gambar vector juga memiliki beban byte yang lebih kecil daripada gambar bitmap.
3. Warna

Perancangan ini akan menggunakan warnawarna yang cerah sehingga khalayak sasaran akan tidak cepat bosan dengan visual yang disajikan.

\section{Tipografi}

Perancangan ini akan menggunakan tipografi sans serif. Tipografi sans serif dirasa cocok untuk perancangan ini karena sederhana dan tingkat keterbacaan yang tinggi.

\section{KONSEP PESAN VERBAL DAN VISUAL}

Konsep pesan verbal dan visual dimulai dari proses produksi sebuah karya desain atau rancangan. Konsep verbal dan visual harus didasari oleh pertimbangan dan perhitungan yang tepat, karena sangat mempengaruhi keberhasilan sebuah karya desain. Konsep tersebut juga harus matang serta didukung oleh kerja kreatif yang tepat agar komunikatif dan menarik.

\section{Konsep Kreatif}

Perancangan ini akan menampilkan media-media yang mengangkat tentang keunikan kue nopia yang membedakan kue tersebut dengan kuliner lainnya. Sehingga mengenalkan nilai kearifan lokal dan membentuk positioning kue nopia pada khalayak sasaran sebagai kuliner khas banyumas. Keunikan tersebut ialah:

a. Nopia pertama dibuat tahun 1880 oleh Ting Sing Piang, seorang etnis Tionghoa yang tinggal di Banyumas 
b. Nopia dibuat dari gentong tanah liat dengan cara ditempel didalam gentong tersebut yang bersuhu 45 derajat Celcius

c. Nopia awalnya cuma ada rasa bawang merah, tapi sekarang sudah ada beraneka rasa yaitu pandan, duren, coklat, dan gula jawa

d. Nopia sering disebut ndog bledeg dan ndog gajah karena ukurannya yang besar

e. Walaupun dimasak dengan cara tradisional, nopia dapat bertahan hingga 3 bulan dari tanggal pembuatannya

\section{Tujuan kreatif}

Tujuan kreatif dari perancangan ini ialah membuat khalayak sasaran paham bahwa nopia merupakan kue khas Banyumas yang memiliki berbagai keunikan yang dapat membedakan kue ini dengan kue lainnya.

\section{Strategi Kreatif}

Strategi kreatif merupakan cara yang dapat dilakukan untuk mencapai hasil dan tujuan yang telah ditentukan yakni dengan cara menyampaikan pesan yang akan dibuat dalam sebuah ide dan konsep perancangan karena tujuan utamanya ialah bagaimana merebut perhatian target audience dengan media yang dipergunakan untuk menyampaikan pesan tersebut. Selanjutnya akan dirumuskan dalam strategi kreatif sebagai berikut:

\section{a. Isi Pesan}

Isi pesan atau yang biasa disebut "what to say" merupakan hal yang penting dalam pembentukan komunikasi visual. Karena isi pesan merupakan pokok-pokok pemikiran yang akan membentuk dasar-dasar dan pendukung tema yang akan dibawa. Hal tersebut menjadi benang merah antara media-media yang digunakan.

Sehubungan dengan perancangan kampanye penggalangan dana ini, isi pesan yang akan dibawakan adalah: "Nopia adalah kuliner unik, khas Banyumas". Walaupun sebagian besar khalayak sasaran mengetahui tentang nopia, namun ternyata mereka tidak tahu bahwa kue ini memiliki berbagai keunikan yang membedakannya dengan kue lainnya. Khalayak sasaran perlu diinformasikan tentang kearifan lokal yang dimiliki oleh kue nopia, sehingga dapat mengangkat khasanah budaya yang terkandung dalam kue nopia.

\section{b. Bentuk Pesan}

Bentuk pesan atau dapat disebut how to say, merupakan perkembangan dari isi pesan. Isi pesan yang telah terbentuk disesuaikan dengan psikologis target audience sehingga pesan yang disampaikan lebih relevan dan menarik bagi target audience. Hal tersebut dapat berupa komunikasi verbal maupun visual.

1) Pesan Verbal

Target audiens adalah anak muda yang tinggal di Jawa, Sumatera, dan Kalimantan, maka perancangan ini akan menggunakan bahasa Indonesia semi formal. Penggunaan bahasa semi formal bermaksud untuk mendekatkan produk ini dengan khalayak sasaran. Perancangan ini juga akan menggunakan hashtag \#faktanopia 
yang akan menjadi keyword utama. Fakta Nopia memiliki arti "semua keunikan-keunikan yang dimiliki oleh nopia”.

\section{2) Pesan Visual}

Bentuk pesan tidak hanya dihadirkan dalam pesan verbal saja namun pesan visual juga harus dihadirkan dan harus lebih memiliki daya tarik yang utama. Perancangan ini akan menggunakan warna merah sebagai background sehingga memudahkan target audiens untuk mengkorelasikan kue nopia dengan budaya tionghoa. Warna merah atau dalam bahasa Cina disebut warna Hong adalah warna penting pada masyarakat Cina. Etnis Tionghoa adalah penyuka warna merah, karena dalam budaya Tionghoa warna ini dianggap sebagai pelambang kebaikan dan kesejahteraan. Merah juga dianggap sebagai lambang kegembiraan dan semangat yang pada akhirnya akan membawa nasib baik.

Warna merah menggambarkan keadaan yang terang dan ceria yang menjadi lambang kegembiraan dan menjanjikan sinar kecerahan dalam kehidupan. Warna merah disebut hong dalam bahasa Cina dan bunyinya kedengaran seperti ong atau bertuah. Maka, masyarakat Cina percaya warna ini akan membawa tuah jika dipakai pada perayaanperayaan mereka.
Karena kue nopia merupakan kue khas banyumas, maka perancangan ini akan membuat sebuah motif yang terinspirasi dari motif batik Banyumas. Batik Banyumasan mempunyai ciri pola batik tersendiri yang merupakan ciri batik pedalaman, yaitu banyak terinspirasi motif tumbuhan dan hewan. Objek-objek yang ditampilkan dalam motif batik ini adalah tanaman-tanaman yang menjadi bahan pokok pembuatan nopia yaitu, gula, tepung terigu, dan vanili.

\section{KONSEP MEDIA}

Konsep media berhubungan dengan media-media terpilih yang akan digunakan dalam perancangan komunikasi visual ini. Konsep media memegang peran penting karena berkaitan dengan pemilihan mediamedia yang efektif dan komunikatif dalam rangka keberhasilan kampanye. Media yang dipilih haruslah dilalui dengan selektif untuk menghindari membuang biaya media. Dalam pembahasan ini konsep media dibagi menjadi dua bahasan yaitu tujuan media dan strategi media. Tujuan media menjelaskan tentang apa yang ingin dicapai dalam media-media yang dipilih. Hal tersebut berkaitan dengan jangkauan, frekuensi, dan kesinambungan atau kontinuitas. Sedangkan strategi media berhubungan dengan langkah-langkah yang ditempuh dalam perancangan media tersebut.

\section{Desain Kemasan}

Kemasan adalah pelindung dari suatu barang, baik barang biasa mau pun barang-barang 
hasil produksi industri. Dalam dunia industri kemasan merupakan pemenuhan suatu kebutuhan akibat adanya hubungan antara penghasil barang dengan masyarakat pembeli. Untuk keperluan ini kemasan harus dapat menyandang beberapa fungsi yang harus dimilikinya seperti:

a. Mutu kemasan dapat menumbuhkan kepercayaan dan pelengkap citradiri dan mempengaruhi calon pembeli untuk menjatuhkan pilihan terhadap barang yang dikemasnya (bungkus rokok yang berwibawa).

b. Kemasan mempunyai kemudahan dalam pemakaiannya (buka, tutup, pegang, bawa) tanpa mengurangi mutu ketahanannya dalam melindungi barang.

c. Rupa luar kemasan harus sesegera mungkin menimbulkan kesan yang benar tentang jenis isi barang yang dikemas.

d. Perencanaan yang baik dalam hal ukuran dan bentuk, sehingga efisien dan tidak sulit dalam hal pengepakan, pengiriman serta penempatan, demikian pula penyusunan dalam lemari pajang.

e. Melalui bentuk dan tata rupa yang dimilikinya kemasan berfungsi sebagai alat pemasar untuk mempertinggi daya jual barang. Dalam fungsi ini desain bentukkemasan harus mendapat dukungan penuh dari unsur desain-grafisnya, sehingga bentuk kemasan selain menarik harus dapat menyampaikan keterangan dan pesan-pesannya sendiri. (Pirous, Error! Hyperlink reference not valid. , diakses 3 Juni 2016)

Perancangan ini akan membuat sebuah kemasan kue nopia yang akan dicetak terbatas hanya 10.000 kemasan saja. Kemasan tersebut dicetak terbatas demi menarik minat khalayak sasaran untuk lekas membeli kue nopia di toko-toko terdekat. Kemasan tersebut akan didistribusikan melalui toko oleh-oleh yang tersebar di beberapa kota besar di Indonesia seperti Yogyakarta, Semarang, Surabaya, Samarinda, Medan, dan Jakarta. Setiap desain kemasan ini akan memberikan informasiinformasi terkait keunikan kue nopia. Informasi tersebut adalah:

a. Nopia pertama dibuat tahun 1880 oleh Ting Sing Piang, seorang orang tionghoa yang tinggal di Banyumas

b. Walaupun dimasak dengan cara tradisional, nopia dapat bertahan hingga 3 bulan dari tanggal pembuatannya

c. Nopia dibikin dari gentong tanah liat dengan cara ditempel didalemnya, panas gentongnya 45 derajat

d. Nopia awalnya cuma ada rasa bawang merah, tapi sekarang sudah ada beraneka rasa yaitu pandan, duren, coklat, dan gula jawa

e. Nopia sering disebut ndog bledeg dan ndog gajah karena ukurannya yang besar

f. Nopia adalah kue hasil akulturasi budaya Tionghoa dan Banyumas

\section{Media Pendukung}

Selain media utama berbentuk desain kemasan, perancangan ini akan membuat media-media pendukung berupa brand activation. Brand activation adalah salah satu bentuk promosi yang mendekatkan merek dengan penggunanya melalui berbagai aktivitas yang menarik perhatian konsumen. Brand Activation membuat interaksi langsung antara Brand dengan konsumen. 
Hal ini tentu akan membuat hubungan konsumen terhadap Brand semakin erat. Ketika hubungan sudah semakin erat maka konsumen akan dengan senang hati membeli produk dan mempromosikan produk suatu brand kepada koleganya. Brand Activation yang dibuat dalam perancangan ini adalah:

\section{a. Floor Display}

Floor Display merupakan salah satu bentuk visual merchandising dengan cara merancang tempat menaruh produk dan ditempatkan diatas lantai. Hal tersebut termasuk dalam menata produk dan menempatkannya pada posisi yang sesuai. Visual merchandising adalah metode penyajian toko dan barang dagangan dengan berbagai cara yang akan menarik perhatian khalayak sasaran dan memotivasi mereka untuk melakukan pembelian. (http://studyvm.blogspot.co.id/2012/01/visual -merchandising.html diakses 27 Mei 2016)

Visual merchandise yang atraktif sangat berperan dalam mempengaruhi khalayak sasaran menentukan produk yang akan dibelinya. Lebih dari itu, visual merchandise juga berperan dalam membentuk persepsi khalayak sasaran terhadap merk tersebut. Visual merchandising sendiri mempunyai beberapa fungsi, yaitu:

1) Meningkatkan daya tarik terhadap merek dan produk tertentu pada rak pajang

2) Mempengaruhi konsumen untuk membeli produk lebih banyak

3) Mendapatkan penjualan dan keuntungan yang lebih besar

\section{b. Media Sosial}

Media sosial berupa akun facebook dan instagram berguna untuk menciptakan engagement antara khalayak sasaran dengan kampanye ini. Strategi ini berfungsi untuk melibatkan khalayak sasaran dalam memberikan komentar dan ulasan tentang nopia. Dengan begitu khalayak sasaran akan merasa lebih dekat dengan kue nopia.

Akun media sosial menciptakan ruang komunikasi antara akun kue nopia dan khalayak sasaran. Akun media sosial instagram dan Facebook akan menyampaikan sebuah kuis yang menyampaikan tentang fakta-fakta kue nopia. Selain me-repost posting pengguna media sosial lain yang memakai hashtag nopia, perancangan ini juga membuat 10 kuis yang akan di-posting setiap 2 hari sekali sejak 22 Februari 2017.

Untuk menambah pengikut, perancangan ini akan menggunakan buzzer media sosial. Buzzer adalah pengguna media sosial yang dapat memberikan pengaruh pada orang lain hanya melalui posting pengguna tersebut. Buzzer tersebut akan me-repost beberapa posting dari akun resmi nopia di facebook dan Instagram.

\section{VISUALISASI}
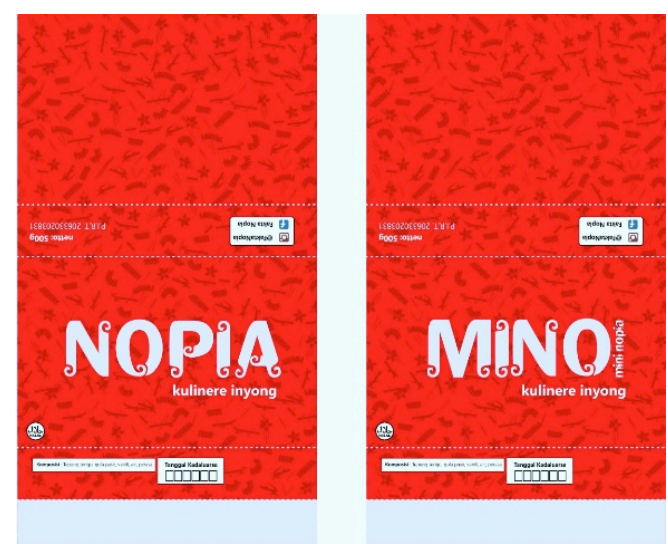

Gambar 4 Kemasan luar kue nopia 

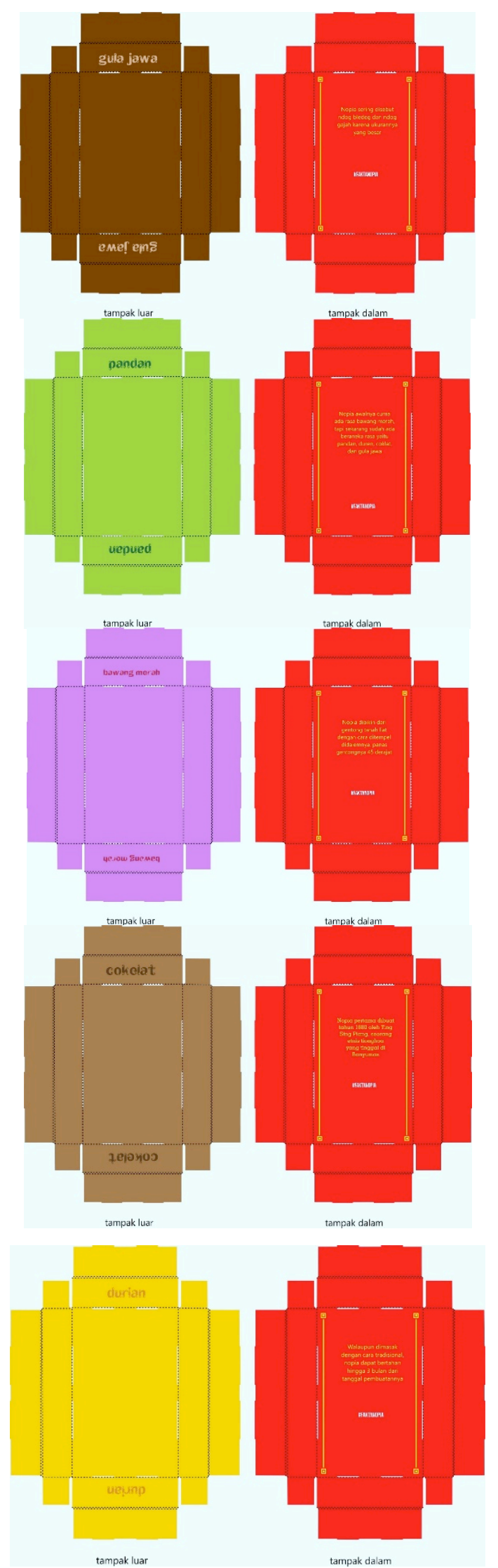

Gambar 5 Kemasan dalam kue nopia

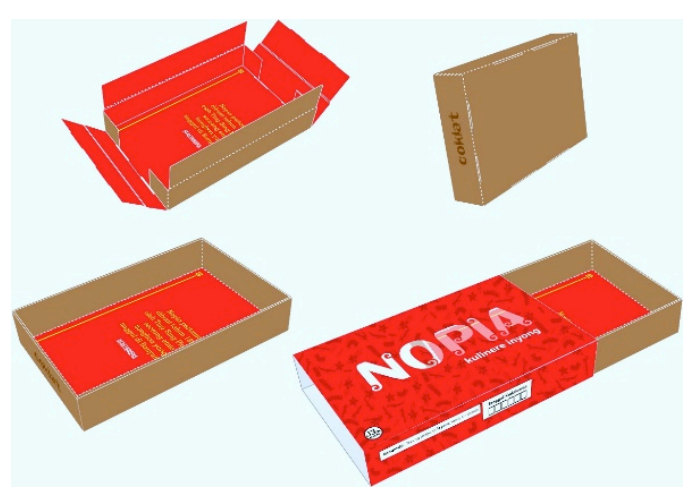

Gambar 6 Final desain kemasan Nopia

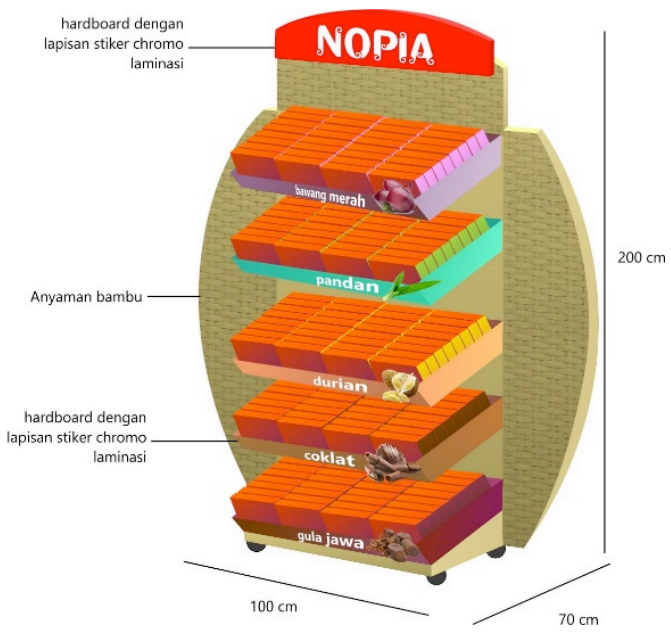

Gambar 7 Final desain floor display

\section{Berikut merupakan} sebutan nopia kecuali?

1. Ndog Bledeg

2. Goyang 45

3. Ndog Gajah

\#faktanopia 

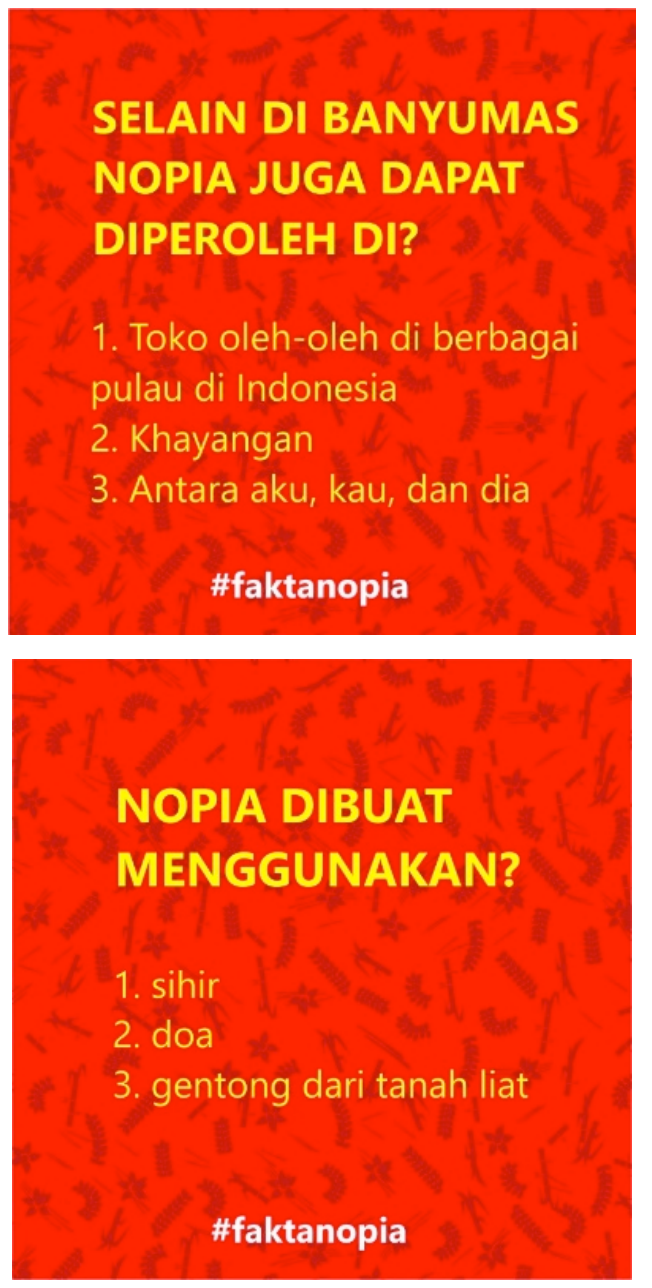

\section{SIAPA YANG} MENCIPTAKAN NOPIA?

1. Pasha Ungu

2. Ting Sing Piang

3. Adam dan Hawa

\#faktanopia
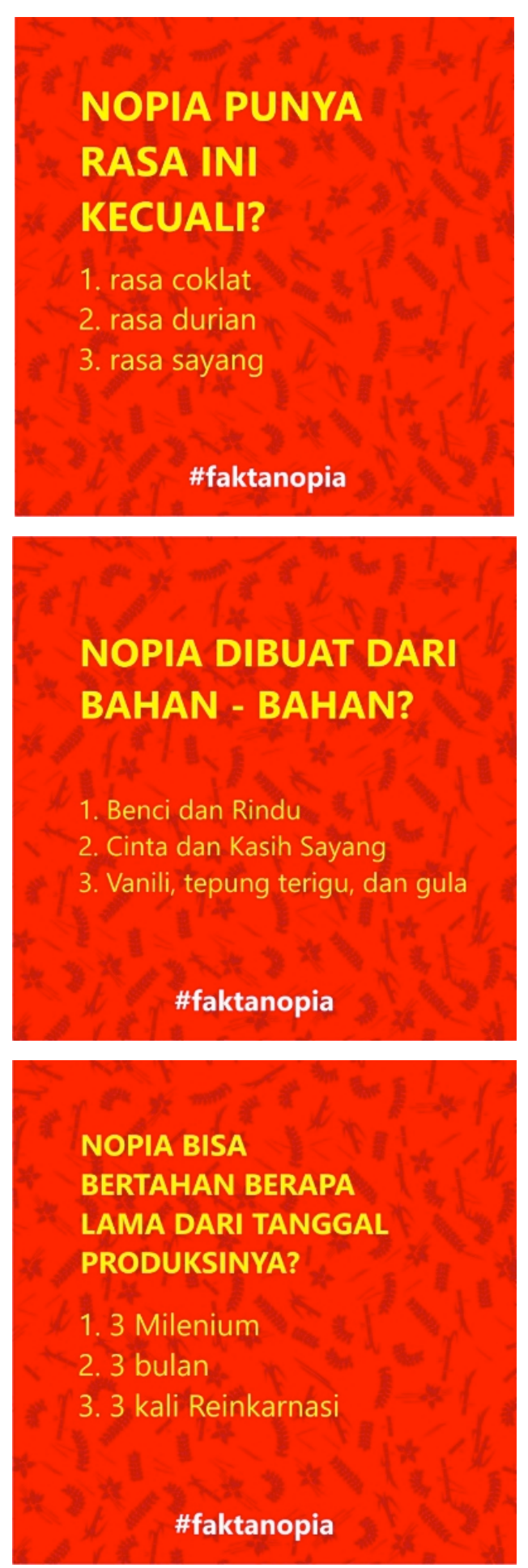

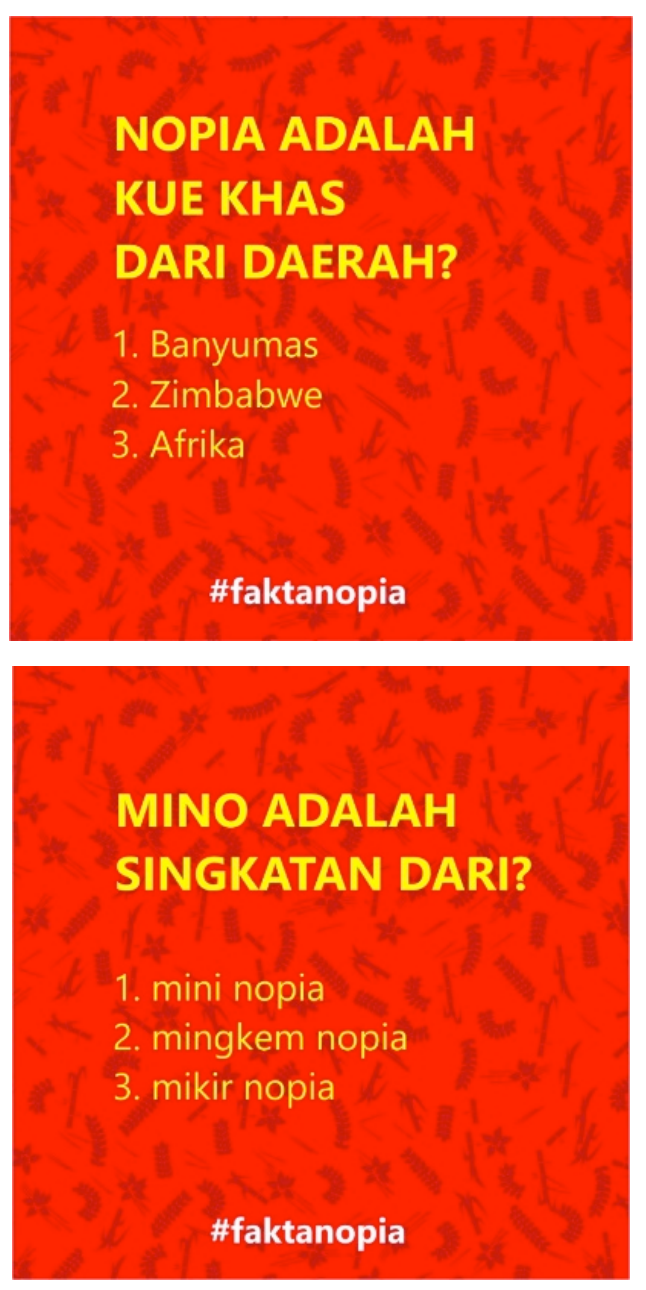

Gambar 8 Desain kuis media sosial

\section{Screenshot Media Sosial}

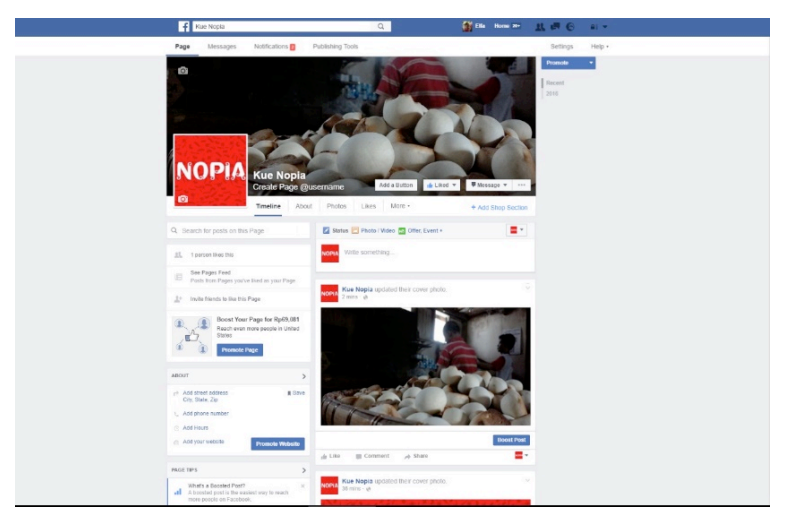

Gambar 9 Screenshot halaman facebook

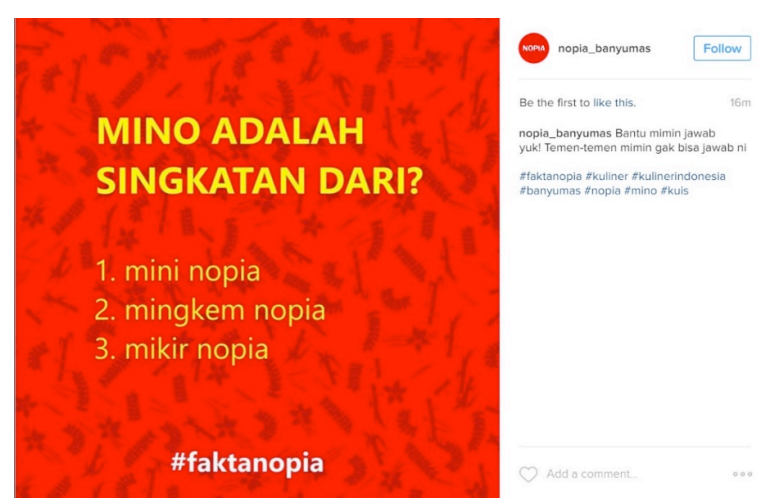

Gambar 10 Screenshot akun instagram

\section{KESIMPULAN}

Nopia adalah kue khas kabupaten Banyumas berbentuk bulat dengan tekstur yang halus, renyah diluar, tapi lembut dibagian tengahnya. Namun, Nopia sebagai kuliner khas Banyumas ternyata tidak banyak orang yang tahu. Bahkan, sebagian responden mengira bahwa makanan yang dimaksud adalah Bakpia. Perlu dirancang suatu komunikasi visual yang mengubah paradigma target audiens yang menyangka bahwa kue nopia dibuat dengan peralatan modern.

Metode pengumpulan data yang digunakan dalam perancangan ini yaitu observasi partisipatoris, wawancara, dokumentasi, dan pustaka, serta perancangan ini melalui 4 tahap, yaitu pembuatan konsep desain, konsep kreatif, konsep media, dan visualisasi.

Berdasarkan data yang dikumpulkan, ditarik kesimpulan bahwa khalayak sasaran memiliki kesibukan yang padat. Khalayak sasaran banyak menghabiskan waktunya di media digital dan komunikasi yang dilakukan banyak melalui aplikasi di telephone genggam. Khalayak sasaran tidak suka berada diluar rumah dengan jangka waktu yang lama. Target audiens hanya bepergian 
kerumah jika ingin membeli kebutuhan saja. Berbicara dan mengobrol dengan temantemannya melalui media sosial. Khalayak sasaran senang berbelanja di supermarket modern. Berdasarkan data tersebut, maka perancangan ini akan menggunakan media kemasan nopia, floor display, dan akun media sosial berupa Facebook dan Instagram.

Proses visualisasi dimulai dengan menentukan konsep desain yang akan diterapkan, yaitu layout sederhana, warna yang cerah, gaya ilustrasi vektor, dan tipografi dengan jenis sans serif. Kemudian konsep pesan verbal dan visual yang digunakan pada perancangan hashtag \#faktanopia yang akan menjadi keyword utama. Fakta Nopia memiliki arti "semua keunikan-keunikan yang dimiliki oleh nopia". Serta visual yang digunakan akan menggunakan warna merah dengan corak yang terdiri dari bahan-bahan dasar kue nopia.

\section{DAFTAR PUSTAKA}

\section{Buku}

[1] Dharmawan, L. 2010. Nopia, Getuk Goreng, dan Sejarah Kuliner Banyumas. Media Indonesia: 9

[2] Kasilo, Djito. 2009. Komunikasi Cinta: menembus G-Spot Konsumen Indonesia, Jakarta: Kepustakaan Populer Gramedia

[3] Kusumohamidjojo, Budiono. 2009. Filsafat Kebudayaan: Proses Realisasi Manusia. Yogyakarta: Jalasutra

\section{Tautan}

[1] http://studyvm.blogspot.co.id/2012/01/vi sual-merchandising.html

Error! Hyperlink reference not valid.

\section{Narasumber:}

Nama : Suparno

Usia: 42 tahun

Pekerjaan: Pengrajin Nopia

Alamat: Jalan Raya Banyumas, Kota Banyumas, Jawa Tengah 